\title{
Investigación, docencia e innovación educativa
}

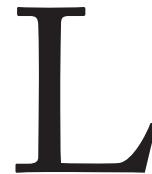

as universidades son instituciones de alta complejidad, por ello se constituyen en ecosistemas, donde, desde luego, la visión holística de todos sus componentes no deja de ser una tarea ardua a la hora de ser coherentes entre lo que se declara y lo que se hace.

Las características inherentes a la propia universidad, desde sus orígenes medievales, ponen en el debate una serie de temas pertinentes, (los cuales, con la universidad moderna, pasan por esa división de universidades profesionalizantes y universidades de investigación) y esa función de compromiso social que se recalca con el movimiento de Córdova.

Uno de esos temas en debate es un marcado divorcio, al menos en nuestro contexto americano, entre la investigación, la docencia y la innovación educativa. De ahí que hoy día se vuelve un imperativo impulsar estrategias creativas y efectivas para su necesaria articulación, que conlleve al logro de mejores resultados y cumplimiento de la responsabilidad que el Estado y la sociedad le han asignado a las universidades.

Como ya es conocido tanto la docencia como la investiga- ción son funciones sustantivas de la universidad afincadas en sus modelos iniciales europeos. En ese trayecto de desarrollo de la educación universitaria y en pleno apogeo de una nueva sociedad marcada por el conocimiento, como mercancía de primer orden, resurge el debate de la ruptura de fronteras entre estas tareas esenciales de las universidades.

Además, aunque no como función sustantiva, sino como un eje trasversal y muy de la mano del principio de pertinencia, se posiciona hoy más que nunca el tema de la innovación educativa como elemento indispensable para la calidad de la educación que brindan las universidades.

A nuestro juicio, ni una ni otra es más importante, las dos son esenciales para que las universidades se mantengan vivas en la era del conocimiento y la era digital, para que cumplan con su rol de formación de ciudadanos del más alto nivel científico, humanístico y cultural y generen conocimiento para el desarrollo humano sostenible.

Ambas son indispensables para garantizar la calidad de una buena enseñanza y por consiguiente de los aprendizajes de las personas que se forman en las diversas áreas del saber humano en sus espacios formativos, de donde deben egresar con las calificaciones y competencias que les lleven a desempeñarse con propiedad en el mundo de hoy.

La discusión se debe en parte, a que la investigación se ha situado, en muchas universidades, en un lugar de preeminencia, siendo el número de investigaciones y publicaciones el mérito de mayor peso para el reconocimiento, méritos y reclasificaciones del profesorado universitario.

Ante este debate, que no es las reflexiones que en 1990 ya hacía el destacado filósofo y educador norteamericano Ernes L. Boyer, en su informe especial Scholarship Reconsidered: priorities of the professoriate, documento donde reflexiona sobre lo que significa ser un académico y las prioridades del profesorado, tras la consulta a 5 mil profesores universitarios.

Boyer propone repensar, de manera más creativa, lo que significa ser un académico de manera que la docencia ocupe, igual que la investigación, un lugar importante y reconocido en las escalas de promoción y reconocimiento que tienen los profesores universitarios. 
A fin de acortar distancia, este filósofo y educador norteamericano plantea la integración de la investigación y la docencia, desde una línea de investigación ligada a indagar sobre la propia docencia y el aprendizaje en las diversas disciplinas de enseñanza y a partir de ello, generar metodologías didácticas que mejoren $\mathrm{y}$ aseguren el aprendizaje de los alumnos.

Las reflexiones de Boyer son retomadas por Pedro Morales, quien en un trabajo publicado en 2010 sobre investigación e innovación educativa plantea la integración de ambas funciones sustantivas desde la investigación pedagógica o educativa, es decir una investigación que tiene como principal laboratorio el propio espacio de aprendizaje, el profesor y los alumnos, es una investigación integrada en el mismo tiempo y proceso docente.
Las tendencias de la educación superior, no dejan duda, cada día cobra mayor relevancia la necesidad de volver visible la calidad de la docencia y del aprendizaje, ya que el propósito de la enseñanza es posibilitar aprendizajes y competencias en los alumnos $\mathrm{y}$ profesores.

Quizás lo obligado es ampliar la visión de lo que implica ser un académico o un profesor universitario y valorar en su justa dimensión el peso de la investigación y de la buena docencia universitaria, pues toda universidad debe presumir de la calidad en ambas funciones y éstas deben mantenerse remozadas a través de procesos innovadores permanentes que las coloquen a la altura de los tiempos y de la sociedad.

Debemos tener en cuenta que el prestigio de una institución de educación superior, se mide en parte, por la calidad de los profesionales que egresan de ella y la misma no cabe dudaestá determinada en gran manera por la excelencia y eficacia de la práctica docente de sus profesores.

$Y$ en el momento actual, donde la obsolescencia del conocimiento, es cada vez más rápida, la universidad debe ser innovadora en todos sus procesos y funciones. La innovación y la creatividad deben ser parte de la agenda cotidiana de las instituciones de educación superior, como un medio para mejorar y cumplir los fines de la educación. 